Article

\title{
Assessment of the Effects of Wastewater Treatment Plant Modernization by Means of the Field Olfactometry Method
}

\author{
Andrzej Kulig and Mirosław Szyłak-Szydłowski *(D) \\ Faculty of Building Services, Hydro and Environmental Engineering, Warsaw University of Technology, \\ 00-653 Warsaw, Poland; Andrzej.Kulig@pw.edu.pl \\ * Correspondence: Miroslaw.Szydlowski@pw.edu.pl
}

Received: 15 October 2019; Accepted: 6 November 2019; Published: 12 November 2019

\begin{abstract}
Methodological aspects of odor studies in ex-post analyses for Polish wastewater management facilities were analyzed based on the example of a modernized and enlarged wastewater treatment plant (WWTP) in Mazovia, in the vicinity of the Warsaw agglomeration. It is a mechanical-biological treatment plant with increased efficiency of biogen removal, using activated sludge in the treatment process, with a maximum hydraulic capacity of $60,000 \mathrm{~m}^{3} /$ day. Olfactometric research was carried out by means of a method based on identification and characterization of the odor plume emitted from the examined source. This paper presents the results of odor intensity assessment (in sensory examinations according to a 6-stage scale) and odor concentration measurement (using portable field olfactometers) after the completion of the project, and compares them with similar studies conducted before the commencement of the investment. A total of 10 measurement series were carried out before modernization, and 12 after modernization of the WWTP. Odor concentration and intensity were determined, and the current meteorological situation was assessed at the measurement and observation points (receptors) located within the premises (in total 462 points) and around the WWTP (342 points). In each series of measurements on the windward side of the treatment plant, the background of air pollution with odorous substances was marked. The research showed that air flowing into the area of the sewage treatment plant is clean in terms of odor. During the research, basic sources of odor nuisance were identified, and their impact before and after modernization was characterized. The results presented in radar diagrams show changes in the percentage distribution of frequency of occurrence of individual intensity values at receptor points within and outside the area of the treatment plant. After modernization, a significant decrease in the concentration of odor emitted from the sludge dewatering building and sludge containers was determined. The air-tightness of the sewage channel (covered with concrete slabs and sealed) resulted in a significant decrease in the concentration of odor emitted from this source. Waste (in particular, sewage sludge) collected in the emergency waste storage yard was identified as the main source of odor nuisance. The waste, even after modernization, was an emitter of odorous compounds spreading outside the area of the WWTP. Nevertheless, as a result of the investment, the desired effect of reduction of the degree of odor nuisance was achieved.
\end{abstract}

Keywords: odor emission; atmospheric dispersion; ambient odor concentration; annoyance; separation distance

\section{Introduction}

Environmental assessments constitute a very important instrument of environmental protection in the economy. Four main types of such assessments can be designated, namely: Forecasts of the 
effects of implementation of a plan, programme, or strategy (i.e., so-called strategic assessments), environmental impact assessments (EIA), as well as post-implementation analyses and environmental audits of the existing installations and objects. The procedure objectives and methods of assessment are different in each case. In Poland, environmental assessments in the sewage management sector play an important role, because it is a sector where many new installations are still introduced, and the existing ones are subject to modernization and enlargement. Moreover, sewage installations are included in a group of objects constituting potential sources of odorant emission-a substantial component of the installation's environmental impact, next to the effect of treated wastewater on the receiver, emission of pollutants to the air and soil, etc. The scope of post-implementation analysis is defined somewhat differently in each case. In general, it should evidence that the newly developed, but also modernized or enlarged object meets the environmental protection standards included in legal provisions and the environmental decision. In the case of implementation of modernization or enlargement of an object, it should be additionally evidenced that the ecological objective of the project was met. Regarding odor impact, the primary objective of the study is the verification that the commissioned object will not constitute nuisance for the other, neighboring land users, and residents in general.

Due to progressing urbanization, the distance between residential areas and municipal installations has decreased. Quality of the environment is difficult to implement in the urban planning process. The planning practice supported by scientific methods should also ensure social consensus combined with achieving environmental standards [1,2]. A commonly used procedure to avoid odor annoyance makes use of separation distances between emission sources and residential areas. Therefore, good planning is a key factor in reducing the occurrence of incompatible land uses near odor-emitting facilities [3].

Odors of anthropogenic origin are usually emitted as a result of industrial, municipal, and agricultural activities, i.e., wastewater and waste management, food industry, rendering plants, livestock buildings, foundries, petrochemical parks, slaughterhouses, paper and pulp facilities, and biosolids [4-18]. The municipal wastewater treatment process, allowing for odor emission reduction, is often omitted, resulting in the unpleasant smell of atmospheric air [19].

Despite their beneficial contribution to environmental protection, municipal wastewater treatment plants (WWTPs) are among potential emission sources of atmospheric pollutants [20]. European countries produce more than 3.5 million $\mathrm{Mg}$ of sewage sludge during the treatment of urban wastewater [21], which must be treated to minimize its negative environmental impacts. According to European regulations, management methods involving solid waste storage are now being replaced by methods leading to waste stabilization and safe recycling [22]. Sometimes, however, before utilization, excessive sludge is stored in emergency sludge storage sites in the area of the treatment plant, causing the emission of odorous compounds. On many occasions, large plants are regarded responsible for emissions of unpleasant odors, because even the surface area occupied by small treatment plants with the throughput of up to $550 \mathrm{~m}^{3}$ a day is relatively high [23]. However, the range of odor impact does not usually exceed $200 \mathrm{~m}$. In addition to that distance, the topographic and meteorological conditions are also of importance [24]. Therefore, odors are a growing problem, not only ecologically, but also socially [24-26]. Odor impact was included in the Biowaste Directive in 2001 as an important factor of waste management.

Recent research has shown that dynamic olfactometry is a technique alternative to monitoring bioprocesses, reducing the number of analyses, their time, and cost [27-32]. The technique followed by dispersion models permits quantification of the odor impact of a process [15].

Different authors have presented information on the characteristics of odors from wastewater treatment processes by means of the olfactometry technique, although, the knowledge to identify odorous emissions from different sources is not yet sufficient $[10,15,24]$. While relationships between odor perception and odorant concentrations have been investigated in the scope of different fields, inter alia living stocks, food waste composting plants, and WWTPs [4,33-36], studies focusing on odor-odorant relationships in wastewater treatment systems have been mostly performed for outdoor 
facilities [37-39]. Methods of assessment of the impacts of odors on communities can be classified according to two distinct approaches, namely: Characterization of the source and prediction of impacts in the surrounding areas (based on dispersion modelling), or direct measurements of impacts in the field. They can be used individually or in combination [40]. Careful investigation of the odor issue requires odorous air measurement employing standardized scientific methods [41]. For years, one of the important research trends in the evaluation of odor nuisance has been the search for devices (and methods) constituting, among others, a reliable and easy-to-use tool, providing answers in real time without the waiting time required by more traditional analytical methods [42].

Field assessments of odor impact can be used to: Monitor daily operations to assess performance; compare operating practices in order to evaluate alternative technologies or management practices in terms of their effectiveness in reducing odor impacts; document specific events or episodes to provide defensible, credible evidence of impact, or lack thereof; monitor compliance with a regulatory limit; evaluate the current status of odor impact to provide baseline data for expansion planning; investigate and evaluate odor control effectiveness; verify dispersion modeling results for the purposes of model improvement or calibration; identify specific odor sources within a community or a particular facility, and examine complaints [43].

In situ measurements can usually be performed using mobile laboratories, even if their provision is very expensive. Instead of direct olfactometry, it is preferable to collect odor samples in situ, and transfer them to an off-site odor laboratory for the assessment [41]. A field olfactometer, however, creates a series of dilutions by mixing the odorous ambient air with odor-free (carbon-filtered) air. Such devices are used in studies regarding the evaluation of odor impact, and have been compared with dynamic olfactometry or electronic noses [41]. Nasal Ranger ${ }^{\circledR}$ field olfactometer is efficient at measuring livestock farm odor, and can provide consistent and accurate measurement results [12].

The use of field olfactometers permits estimation of odor concentration directly in a given measurement point. Olfactometric examinations provide information allowing for the verification of residents' complaints concerning odor nuisance, and estimation of the hedonic quality of the odor. Field olfactometers are also used to estimate odor intensity in the atmospheric air near municipal WWTPs [24]. Accurate characterization of odorous emissions is very important in WWTP odor management. Odors must be quantitatively translated in order to be objectively legislated and monitored [44]. Detailed characterization in terms of composition and odorant concentration is also necessary to optimize the design and management of odor abatement systems, improve our understanding of the mechanisms of odor formation and degradation, and their monitoring [45-48].

In Poland, in spite of various attempts at legislative action over the last dozen years, the issue of the odor quality of air is still not subject to strict methodical procedures or legal regulations. Nonetheless, the problem of the impact of odorants on the surroundings is taken into consideration in environmental assessments, among others of WWTPs. The basic assessment of the type and intensity of the impact of technological objects can be performed through the comparison of concentrations of pollutants (odorants) in atmospheric air and/or characterizing (in terms of intensity and concentration) odor in points downwind of the object towards the upwind background. The odor impact of WWTPs particularly depends on periodical changes in physicochemical parameters of supplied sewage, and seasonal and daily changes in the meteorological conditions (e.g., wind direction and speed, air temperature, and humidity), as well as, to no lesser degree, changes in the technological conditions (e.g., conducting the process of sludge processing, efficiency of air deodorization, etc.).

Both the cited researchers and executors of monitoring research in the scope of commercial projects have mainly focused either on emission from particular surface sources, or on the effect of the wastewater treatment plant outside its premises. In the second case, the grid method is particularly applied, determining a priori distribution of points, independent from meteorological conditions (wind direction), permitting the determination of long-term mean values of odor concentrations. In the current study, an extensive, complex methodology based on the plume method is proposed, involving the use of field olfactometers in year-round research. Moreover, particular attention was paid to 
each time identification of odor sources, and research on their range involving several degrees-with decreasing odor intensity values and increasing distance from the source on the downwind side. Such research is less labor-intensive and time-consuming than standard procedures in the grid method, and at the same time, allows for the development of a comprehensive "odor map" of average values of instantaneous concentrations for the WWTP, taking into account both the diversity of sources and changes resulting from meteorological conditions. The application of the plume method is more beneficial from the point of view of comparative inference concerning the effects of modernization and potential odor nuisance of the installation. So, the aim of this work is to describe the application of site-adapted plume field inspection method to evaluate the odor impact on the downwind relative to the considered sources. The plume method, described in the European Standard VDI 3940 [49], was adapted according to the specific area of the WWTP. Therefore, the present paper has the goal of using that method to compare effectiveness of WWTP modernization.

\section{Methodology}

\subsection{Schedule, Methods, and Scope of Research}

The objective of the study was the assessment of the effect of a modernized and enlarged WWTP on the intensity of odor impact within and outside its area. The analysis of environmental impacts was performed with consideration of the seasonality of phenomena and processes. Tables 1 and 2 include the schedule and scope of research, as well as main meteorological conditions before and after modernization of the plant.

Table 1. Schedule, scope of olfactometric research, and meteorological conditions before waste water treatment plant (WWTP) modernization.

\begin{tabular}{|c|c|c|c|c|c|c|c|c|c|c|}
\hline \multirow{2}{*}{$\begin{array}{l}\text { Series } \\
\text { No. }\end{array}$} & \multirow{2}{*}{$\begin{array}{l}\text { Date of } \\
\text { Research }\end{array}$} & \multicolumn{2}{|c|}{$\begin{array}{c}\text { Number of Receptors } \\
\text { (points) }\end{array}$} & \multirow[b]{2}{*}{ Total } & \multicolumn{2}{|c|}{$\begin{array}{l}\text { Wind Speed } \\
(\mathrm{m} / \mathrm{s})\end{array}$} & \multicolumn{2}{|c|}{$\begin{array}{l}\text { Temperature } \\
\left({ }^{\circ} \mathrm{C}\right)\end{array}$} & \multicolumn{2}{|c|}{ Humidity (\%) } \\
\hline & & $\begin{array}{c}\text { Within the } \\
\text { Treatment } \\
\text { Plant }\end{array}$ & $\begin{array}{c}\text { Outside the } \\
\text { Treatment } \\
\text { Plant }\end{array}$ & & Min & Max & Min & Max & Min & $\operatorname{Max}$ \\
\hline I & 28.04 .2015 & 24 & 12 & 36 & 0.8 & 3.2 & 21.6 & 24.4 & 40.0 & 63.2 \\
\hline II & 05.05.2015 & 24 & 12 & 36 & 0.4 & 3.8 & 25.1 & 26.4 & 40.3 & 43.7 \\
\hline III & 11.05 .2015 & 24 & 12 & 36 & 0.9 & 2.3 & 11.0 & 12.9 & 58.4 & 71.2 \\
\hline IV & 14.05 .2015 & 24 & 12 & 36 & 1.0 & 1.9 & 12.2 & 14.6 & 48.0 & 78.4 \\
\hline $\mathrm{V}$ & 19.05 .2015 & 12 & 24 & 36 & 1.0 & 4.0 & 25.0 & 26.5 & 33.0 & 38.3 \\
\hline VI & 20.05.2015 & 12 & 24 & 36 & 1.1 & 1.8 & 23.5 & 25.8 & 55.6 & 59.2 \\
\hline VII & 22.05 .2015 & 12 & 24 & 36 & 1.2 & 2.7 & 19.2 & 22.8 & 32.2 & 1.6 \\
\hline VIII & 27.05.2015 & 6 & 30 & 36 & 2.4 & 3.8 & 13.5 & 15.0 & 56.5 & 66.1 \\
\hline IX & 29.05.2015 & 12 & 24 & 36 & 0.9 & 1.9 & 19.5 & 21.6 & 38.0 & 50.2 \\
\hline$x$ & 03.06 .2015 & 12 & 24 & 36 & 1.7 & 3.8 & 28.8 & 30.5 & 32.1 & 34.7 \\
\hline Total: & - & 162 & 198 & 360 & - & - & - & - & - & - \\
\hline
\end{tabular}

Table 2. Schedule, scope of olfactometric research, and meteorological conditions after WWTP modernization.

\begin{tabular}{|c|c|c|c|c|c|c|c|c|c|c|}
\hline \multirow{2}{*}{$\begin{array}{l}\text { Series } \\
\text { No. }\end{array}$} & \multirow{2}{*}{$\begin{array}{l}\text { Date of } \\
\text { Research }\end{array}$} & \multicolumn{2}{|c|}{$\begin{array}{l}\text { Number of Receptors } \\
\text { (points) }\end{array}$} & \multirow[b]{2}{*}{ Total } & \multicolumn{2}{|c|}{$\begin{array}{c}\text { Wind Speed } \\
(\mathrm{m} / \mathrm{s})\end{array}$} & \multicolumn{2}{|c|}{ Temperature (\%) } & \multicolumn{2}{|c|}{ Humidity (\%) } \\
\hline & & $\begin{array}{l}\text { Within the } \\
\text { Treatment } \\
\text { Plant }\end{array}$ & $\begin{array}{l}\text { Outside the } \\
\text { Treatment } \\
\text { Plant }\end{array}$ & & Min & Max & Min & Max & Min & $\operatorname{Max}$ \\
\hline I & 20.05 .2016 & 36 & 12 & 48 & 0.9 & 2.5 & 19.3 & 30.8 & 21.2 & 34.2 \\
\hline II & 16.06 .2016 & 24 & 12 & 36 & 0.4 & 4.7 & 19.8 & 24.7 & 52.0 & 68.3 \\
\hline III & 13.07.2016 & 24 & 12 & 36 & 0.3 & 1.4 & 24.1 & 29.5 & 4.7 & 67.2 \\
\hline IV & 02.08 .2016 & 24 & 12 & 36 & 0.4 & 1.9 & 18.0 & 26.4 & 49.8 & 76.7 \\
\hline V & 18.08.2016 & 24 & 12 & 36 & 0.5 & 1.9 & 18.9 & 23.1 & 44.7 & 58.9 \\
\hline VI & 08.09.2016 & 24 & 12 & 36 & 0.5 & 1.5 & 26.9 & 33.0 & 38.5 & 53.0 \\
\hline
\end{tabular}


Table 2. Cont.

\begin{tabular}{|c|c|c|c|c|c|c|c|c|c|c|}
\hline \multirow{2}{*}{$\begin{array}{l}\text { Series } \\
\text { No. }\end{array}$} & \multirow{2}{*}{$\begin{array}{l}\text { Date of } \\
\text { Research }\end{array}$} & \multicolumn{2}{|c|}{$\begin{array}{l}\text { Number of Receptors } \\
\text { (points) }\end{array}$} & \multirow[b]{2}{*}{ Total } & \multicolumn{2}{|c|}{$\begin{array}{l}\text { Wind Speed } \\
\qquad(\mathrm{m} / \mathrm{s})\end{array}$} & \multicolumn{2}{|c|}{ Temperature (\%) } & \multicolumn{2}{|c|}{ Humidity (\%) } \\
\hline & & $\begin{array}{l}\text { Within the } \\
\text { Treatment } \\
\text { Plant }\end{array}$ & $\begin{array}{l}\text { Outside the } \\
\text { Treatment } \\
\text { Plant }\end{array}$ & & Min & Max & Min & Max & Min & $\operatorname{Max}$ \\
\hline VII & 19.10.2016 & 24 & 12 & 36 & 0.3 & 1.5 & 11.9 & 14.3 & 62.4 & 73.6 \\
\hline VIII & 23.11.2016 & 24 & 12 & 36 & 0.4 & 1.7 & 7.8 & 10.4 & 64.2 & 74.3 \\
\hline IX & 25.01.2017 & 24 & 12 & 36 & 0.3 & 1.9 & 1.9 & 4.5 & 76.3 & 87.0 \\
\hline$x$ & 24.02.2017 & 24 & 12 & 36 & 0.5 & 5.0 & 3.0 & 4.4 & 86.9 & 98.1 \\
\hline XI & 29.03 .2017 & 24 & 12 & 36 & 0.4 & 5.3 & 10.2 & 13.6 & 74.5 & 85.0 \\
\hline XII & 26.04 .2017 & 24 & 12 & 36 & 0.4 & 1.4 & 7.9 & 9.8 & 72.3 & 85.0 \\
\hline Total: & - & 300 & 144 & 444 & - & - & - & - & - & - \\
\hline
\end{tabular}

The scope of assessment of the odor nuisance caused by the WWTP covered field measurements and observations of the odorimetric quality of air with measurements and observations of instantaneous meteorological conditions at each receptor point. Due to the variability and intensity of the odor impact, it was necessary to conduct field research at different times, from 08:00 to 20:00.

Researchers were selected and tested each time before starting the field studies using the Sniffin' Sticks Test (SST) according to ISO 13301:2002.

The plume method is a short period experiment (several times of approximately half a day under meteorological conditions) to determine the extent of recognizable odor from a specific source-area where the plume originating from a specific odor source or an odor emitting installation can be perceived and recognized [49-52]. The odor plume extent is described by points where there occurs a transition from absence to presence of the recognizable odor under investigation. Panel members are used to determine the presence or absence of the specific odor under study at different points downwind of a source under well-defined meteorological conditions. The meteorological conditions during the field observations are measured and recorded [52]. There are two versions of plume measurement: Stationary and dynamic plume methods. During the research campaign, the second of these methods was used. Using the dynamic method, the panel members traversed the plume, while conducting single measurements at frequent intervals [52]. So, researchers each time identified individual sources of odor emissions, determined odor intensity, basic meteorological parameters, and odor concentration. Then, moved away, along with the wind direction, testing the above parameters until the odor effect disappeared.

The research employed Nasal Ranger ${ }^{\circledR}$ (St. Croix Sensory, Inc., Stillwater, MN, USA) devices. They permit creating calibrated series of dilutions through mixing air contaminated with odorants with filtrated air with no odorants. The analysis of odor nuisance in the field by means of a Nasal Ranger ${ }^{\circledR}$ olfactometer is a method of quantitative determination of odor concentration, expressed as dilution-to-threshold ratios $(\mathrm{D} / \mathrm{T})$. The $\mathrm{D} / \mathrm{T}$ value is the number of dilutions required to obtain a dilution in the surrounding air at which odor is imperceptible. The application of a Nasal Ranger ${ }^{\circledR}$ olfactometer permits the calculation of the $\mathrm{D} / \mathrm{T}$ value, and provides the basis for the determination of the value of odor intensity, expressed as cod in odor units (ou-odor unit, analogically to European norm PN-EN 13725:2007) per volume unit $\left(\mathrm{ou} / \mathrm{m}^{3}\right)$. Based on the $\mathrm{D} / \mathrm{T}$ values, the individual odor concentration values were calculated using the following formulas:

$$
Z_{\text {yes }}=(D / T)_{y e s}+1
$$


where $Z_{\text {yes }}=$ dilution ratio, at which the odor became perceptible, $(D / T)_{y e s}=$ dilution ratio corresponding to the moment when the odor became perceptible for the first time,

$$
Z_{n o}=(D / T)_{n o}+1
$$

where $Z_{n o}=$ dilution ratio, at which the odor was imperceptible, $(D / T)_{n o}=$ dilution ratio corresponding to the moment when the odor was imperceptible just before the dilution $(D / T)_{\text {yes }}$,

$$
Z_{I T E}=\sqrt{Z_{\text {yes }} \times Z_{n o}}
$$

where $Z_{I T E}=$ individual odor threshold estimate. Values of the odor concentration were calculated as a geometric mean of the set of all individual estimations $\left(Z_{\text {ITE }}\right)$ for a given receptor point using the formula:

$$
c_{o d}=\sqrt[n]{\sum_{i=1}^{n} Z_{I T E, i}}
$$

where $c_{o d}=$ value of odor concentration $\left(\mathrm{ou} / \mathrm{m}^{3}\right)$, and $n=$ number of all individual estimates.

\subsection{General Characteristics of the WWTP}

Referring to the management of the treatment plant, before modernization of the object, sewage from the catchment was supplied to the main pumping station equipped with coarse screens with a $20 \mathrm{~mm}$ grid. From there, sewage was introduced by means of pumps to the plenum system in front of the fine screens building, where three screens with a $3 \mathrm{~mm}$ grid and screening-washing press functioned together with the transport system and auxiliary devices. Further, sewage was supplied to a two-chamber covered aerated sand trap, and then introduced to three radial horizontal settling tanks, serving the function of primary settling tanks. Next, mechanically-treated wastewater was transferred to equalizing tanks, from where it was directed to four biological reactors operating in the active sludge technology. Each of the bioreactors included a pre-denitrification zone, anaerobic mixing chamber, denitrification chamber, and nitrification chamber. From the biological reactors, wastewater, together with active sludge, was supplied to four radial horizontal secondary settling tanks, and then after its separation from biomass, discharged to the river. Sludge retained in the primary settling tanks was directed to gravity thickeners, and sludge after biological treatment, to mechanical thickeners. After mixing and macerating, sludge was subject to stabilization in designated closed anaerobic digestion chambers, and then mechanically dewatered in centrifuges. The dewatered sludge was stored in the area of the WWTP. The installation of sewage treatment comprised a functioning extensive system of air-tightening of technological objects and deodorization of polluted air before its introduction to the atmosphere. The deodorization system consisted of 8 biological filters.

Modernization, that took place in 2014-2015, involving, among others, the incorporation of two biological reactors and secondary settling tanks into the technological sequence, as well as air-tightening of the sewage canal. The map of the sewage treatment plant after modernization, together with the basic sources of odor emission, is presented on Figure 1. 


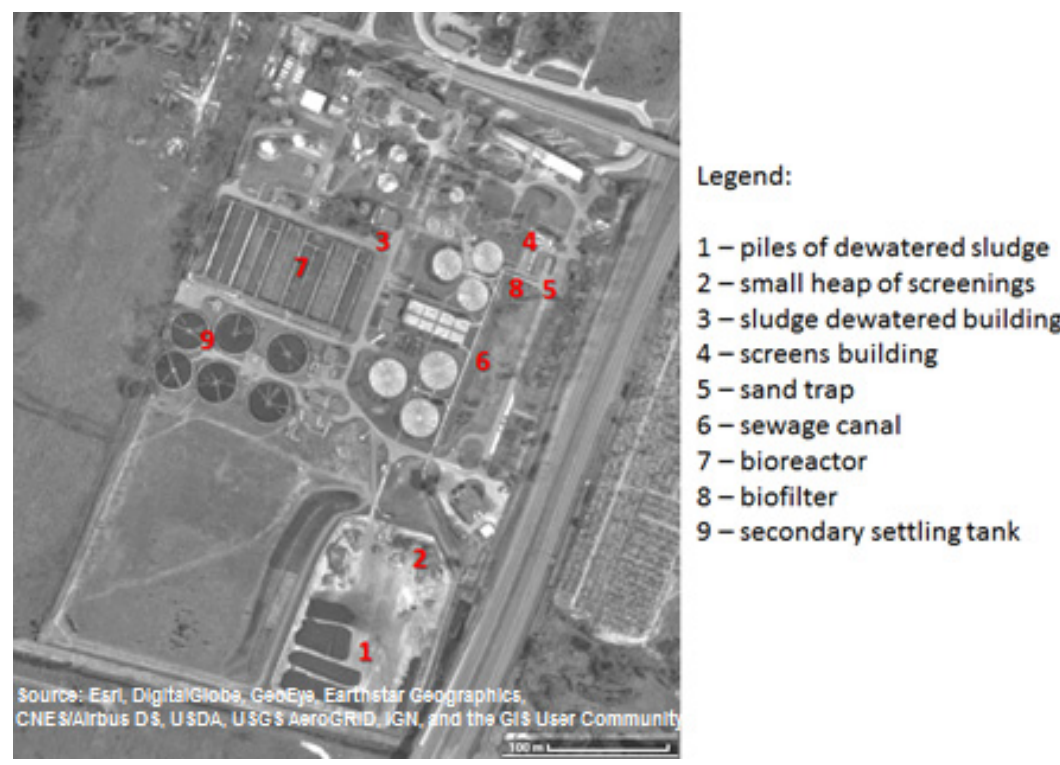

Figure 1. Map of the sewage treatment plant after modernization, together with the basic sources of odor emission.

\section{Results}

Results of investigations before modernization of the WWTP are presented in Figure 2: Spatial distribution of odor concentration values; Figure 3: Range of impact of particular sources of odor nuisance; and Figure 4: Spatial distribution of odor concentration values after modernization. Figures 2 and 4 contain all results of odor concentrations achieved during 10 (360 points) and 12 series (444 points), respectively. Figure 5 presents maximum values of odor concentration recorded on the downwind side of particular sources of odor nuisance before and after modernization of the object.

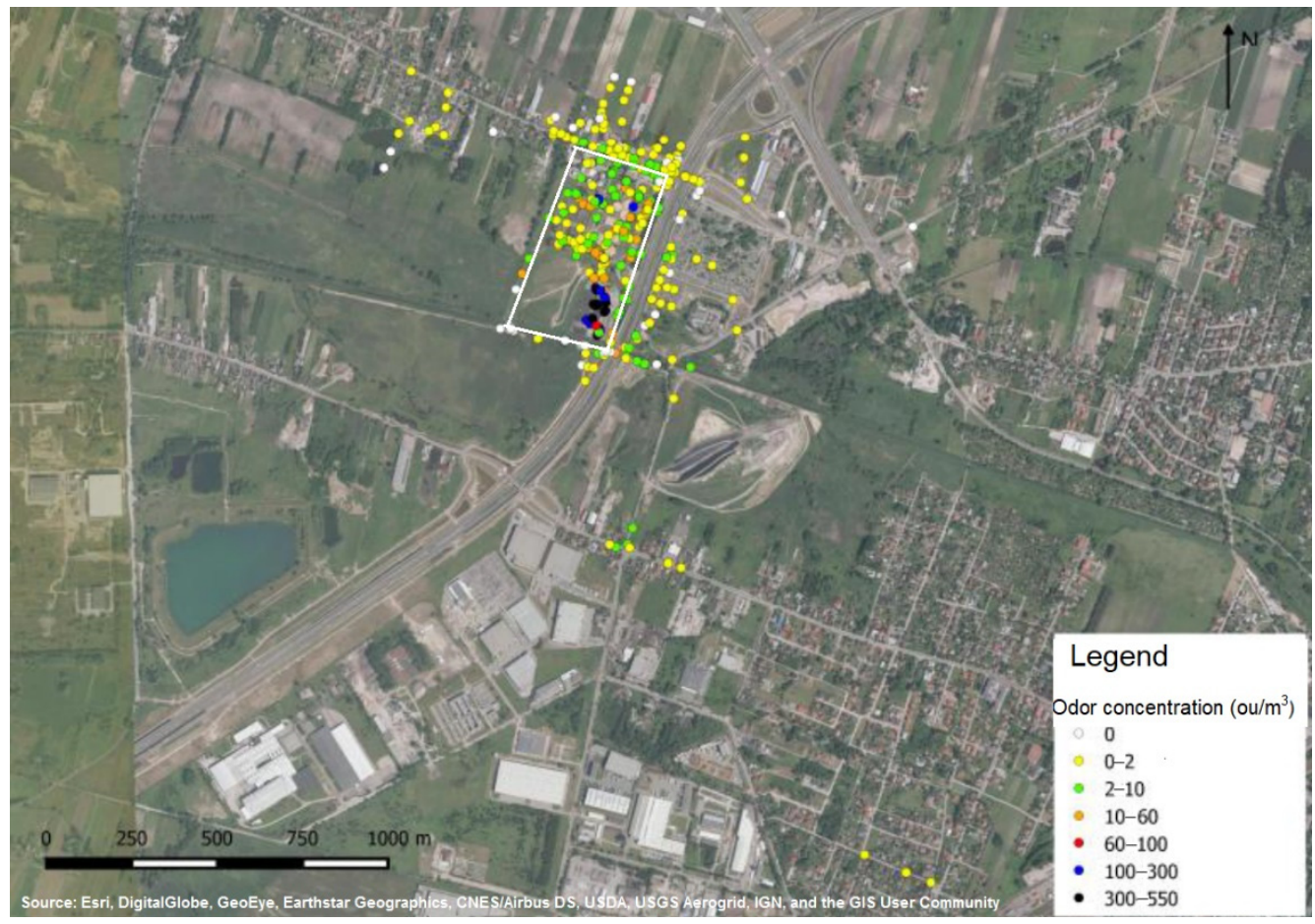

Figure 2. Spatial distribution of odor concentration values before modernization. A white parallelogram indicates the boundaries of the WWTP. 


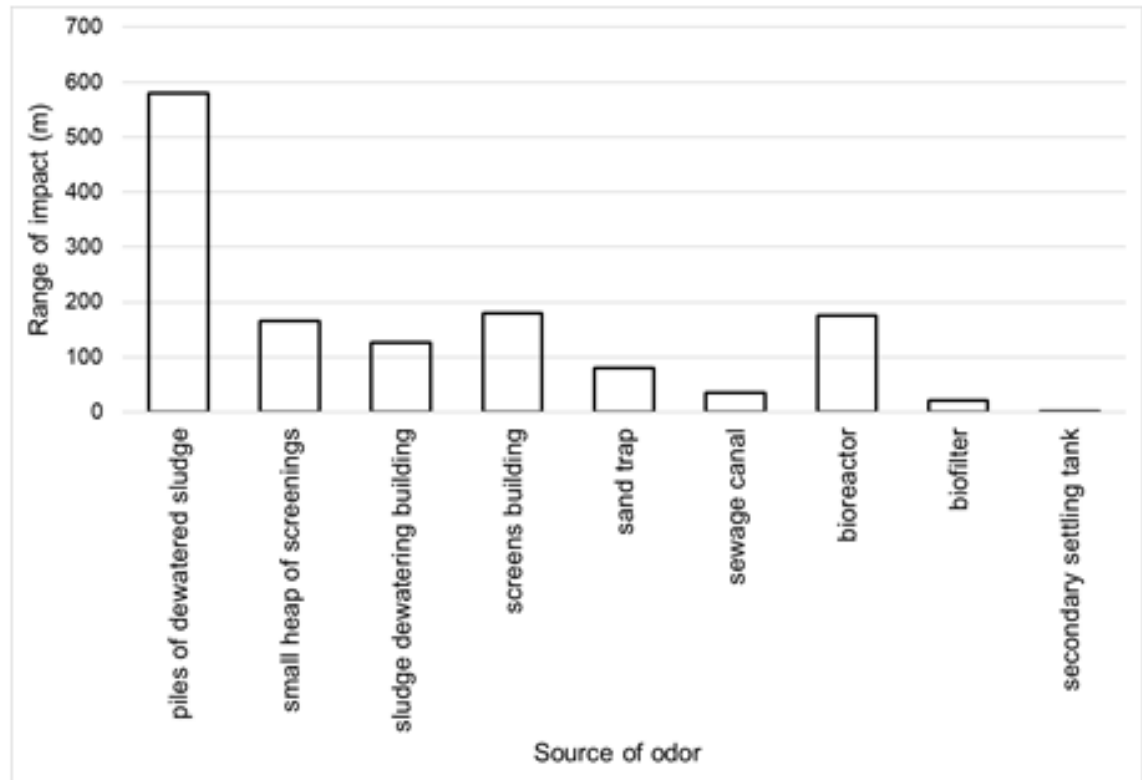

Figure 3. Range of impact of particular sources of odor nuisance before modernization of the object.

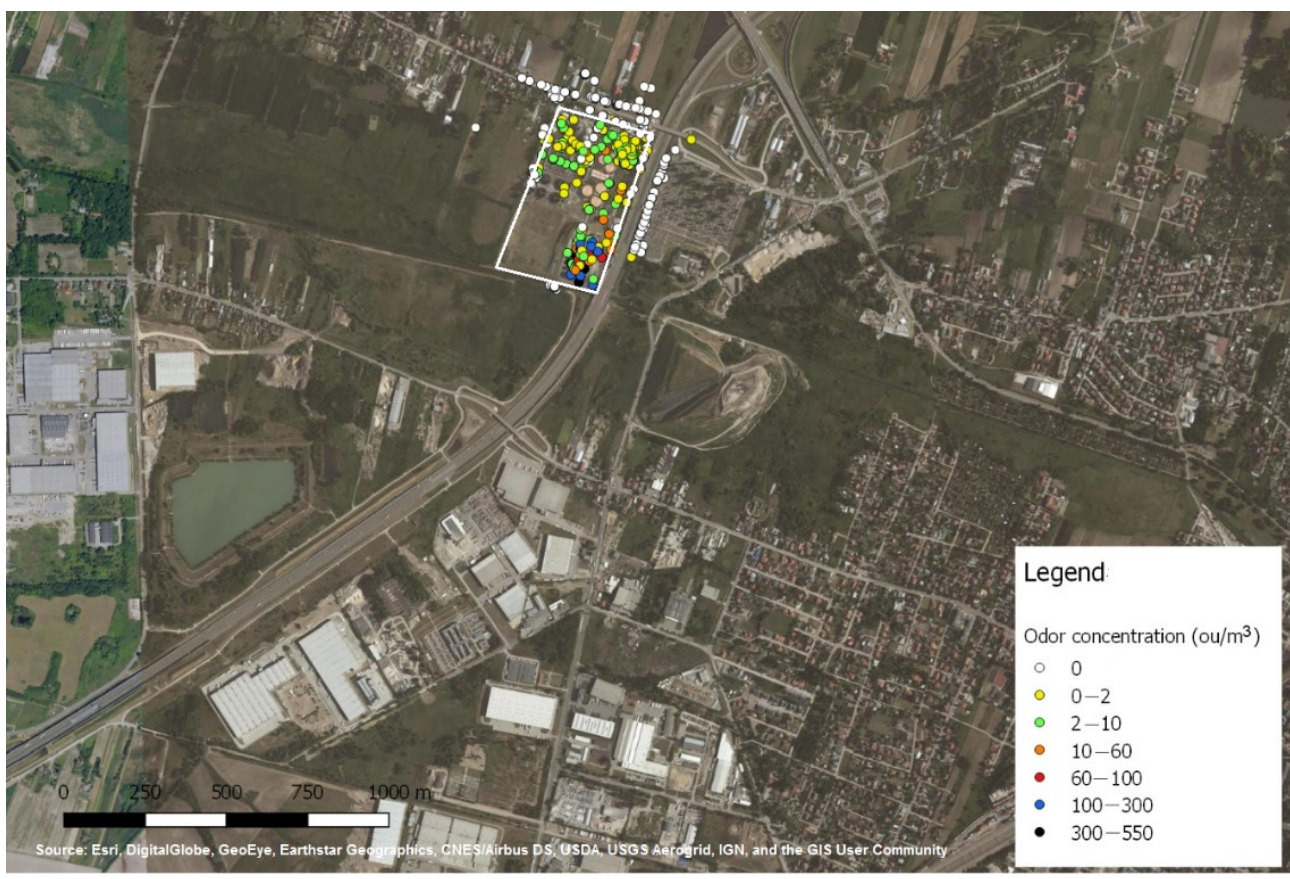

Figure 4. Spatial distribution of odor concentration values after modernization. A white parallelogram indicates the boundaries of the WWTP.

As explained in the methodological section, results were obtained using the plume method. Researchers determined the extent of recognizable odor from each source, identified during examinations. So, range of impact of those particular sources of odor is described by the point where a transition from absence to presence of the recognizable odor was found.

Before modernization, main sources of odor nuisance outside the WWTP were: Piles of dewatered sludge, screens building, sewage canal, and bioreactor. At some points located outside the WWTP, the intensity of the odor value was 3-the source of that nuisance was storage yard of dewatered sludge. 

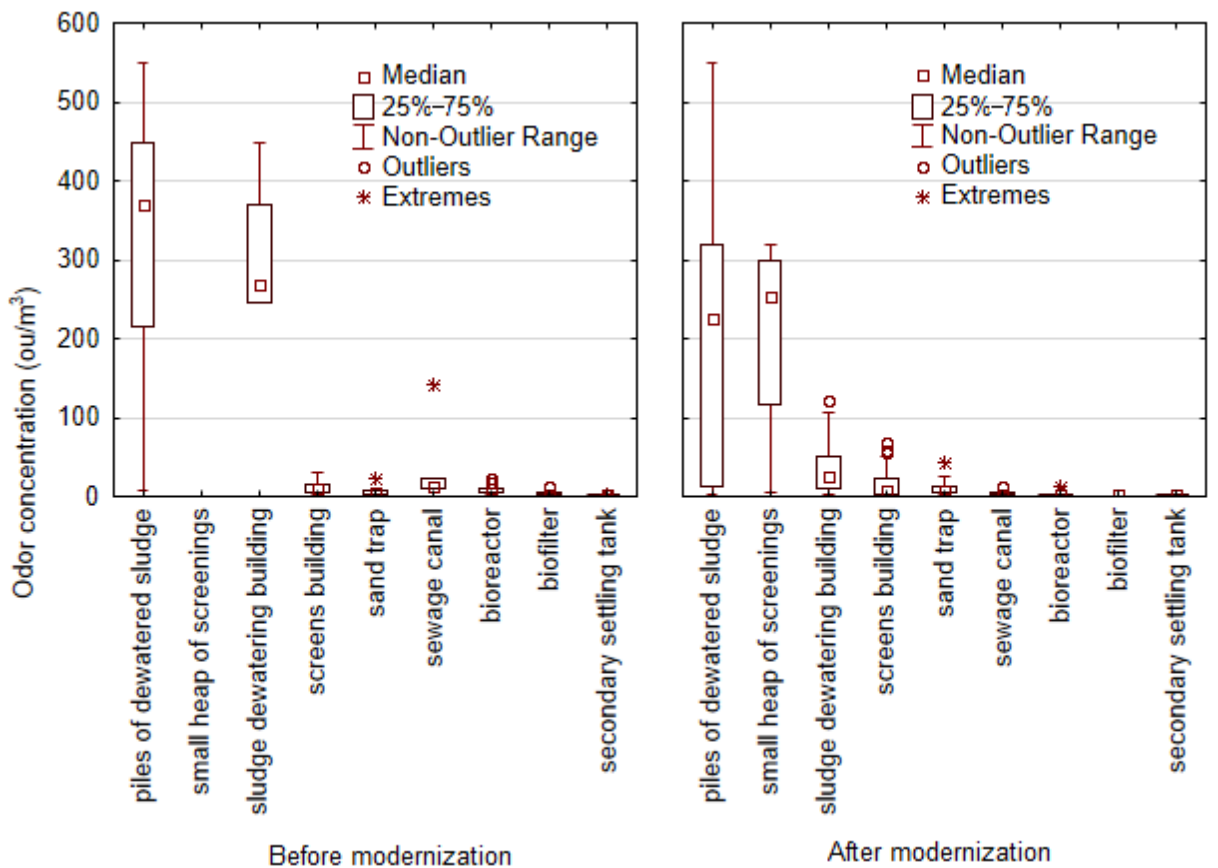

Odor source

Figure 5. Maximum values of odor concentration recorded downwind of particular sources depending on the source of odor nuisance before and after modernization of the object.

After modernization, out of 144 points outside of the WWTP, odor impact of the object was recorded in 10 receptor points. Sources of odor nuisance included:

- Screens building (2 points)—odor concentration $2 \mathrm{ou} / \mathrm{m}^{3}$, maximum range $180 \mathrm{~m}$. The odor of screenings was perceptible outside the area of the WWTP.

- Piles of dewatered sludge (6 points)—odor concentration $2-3 \mathrm{ou} / \mathrm{m}^{3}$, maximum range $580 \mathrm{~m}$. The odor of excess sludge was perceptible outside the WWTP.

- Small heap of screenings (2 points)—odor concentration $2 \mathrm{ou} / \mathrm{m}^{3}$, maximum range $166 \mathrm{~m}$. The odor of screenings was perceptible outside the WWTP.

As already mentioned, modernization involved, among others, the incorporation of two biological reactors and two secondary settling tanks into the technological sequence. Considering the comparison of results of olfactometric research before and after modernization, the incorporation of the aforementioned objects in the technological sequence did not affect concentration values of odor emitted from the sources. The maximum concentration value of odor emitted from the bioreactor before modernization was $19 \mathrm{ou} / \mathrm{m}^{3}$, and after modernization, $14 \mathrm{ou} / \mathrm{m}^{3}$, whereas, in the case of secondary settling tanks, the values were $4 \mathrm{ou} / \mathrm{m}^{3}$ and $2 \mathrm{ou} / \mathrm{m}^{3}$, respectively. After modernization, a considerable reduction of the concentration value of odor emitted from the sludge dewatering building and sludge containers was obtained. The maximum concentration value of odor from the sludge dewatering building before modernization was $448 \mathrm{ou} / \mathrm{m}^{3}$, and after modernization, $123 \mathrm{ou} / \mathrm{m}^{3}$. Due to the air-tightening of the sewage canal (covering it with concrete slabs and sealing), a substantial reduction of the concentration value of odor emitted from the source was obtained. The odor nuisance from the sewage canal was only observed in two initial series (I and III). Emission of odor compounds occurred through a crevice between concrete slabs. The maximum odor concentration value was $22 \mathrm{ou} / \mathrm{m}^{3}$, and the range of impact was $33 \mathrm{~m}$.

The primary source of odor nuisance, both before and after modernization, was waste stored in the emergency waste storage yard. Piles of sewage sludge and a small heap of screenings deposited in the yard constituted emitters of odorous substances spreading outside the area of the WWTP. Before and 
after modernization, the recorded maximum concentration of odor from the piles of dewatered sludge was $549 \mathrm{ou} / \mathrm{m}^{3}$. Before modernization, no deposition of screenings was observed in the yard, and after modernization, the maximum concentration of odor from the small heap of screenings was $319 \mathrm{ou} / \mathrm{m}^{3}$. For the purpose of presentation of the change in the range of odor impact of the WWTP before and after modernization, characterized by means of the observed odor intensity values, radar diagrams were used. They present the percent distribution of the frequency of occurrence of particular values of $i=0-5$ in the area of the WWTP and in its direct vicinity. Figure 6 presents the situation in the area of the WWTP before its modernization (Figure 6a) and after the completion of the investment (Figure $6 b$ ). The comparison of the diagrams shows a decrease in the contribution of intensity of $i=5$ (by $2.5 \%$ ), with a simultaneous increase in the number of values of $i=4$ (by $2.2 \%$ ). A decrease was recorded in the contribution of the intensity of $i=3$ (by $8.5 \%$ ) and considerably $i=2$ (by $12.4 \%$ ), with a simultaneous several percent (by $3.4 \%$ ) increase in the number of results of $i=1$, and exactly $17.9 \%$ increase in the contribution of situations in which no odor was observed ( $i=0$, with no odor impact, completely imperceptible).
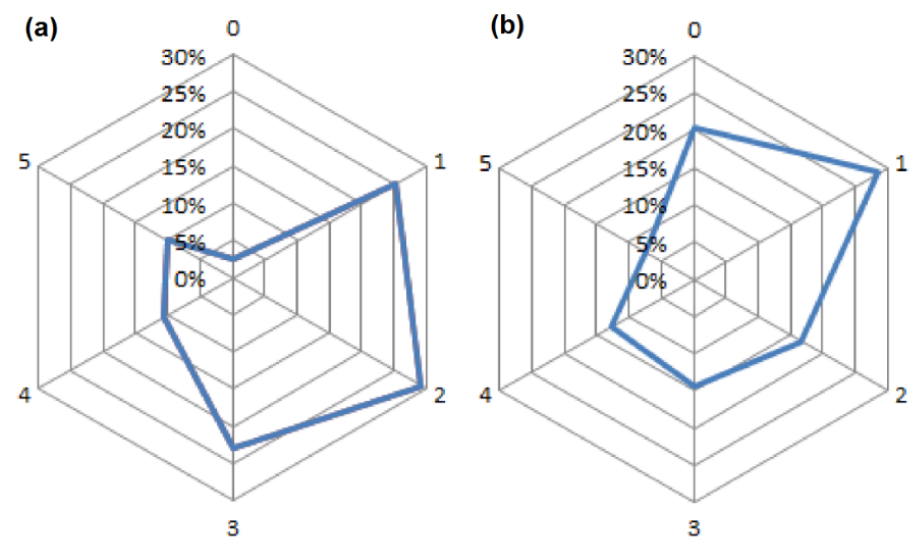

Figure 6. Percent distribution of frequency of occurrence of particular odor intensity values in receptor points in the area of the WWTP: (a) before modernization; (b) after modernization.

Results of the assessment of the odor impact of the WWTP outside its area are presented in Figure 7. In this case, changes are even more evident. In the case of lack of determination of intensity $i=3,4$, and 5 in research before modernization, in research after modernization, no intensity $i=2$ was additionally observed. The contribution of odor intensity $i=1$, which before modernization was observed in $58.6 \%$ of cases, decreased to several percent (by precisely $53.0 \%$ ), and more than $90 \%$ of observations confirmed no odor occurrence.

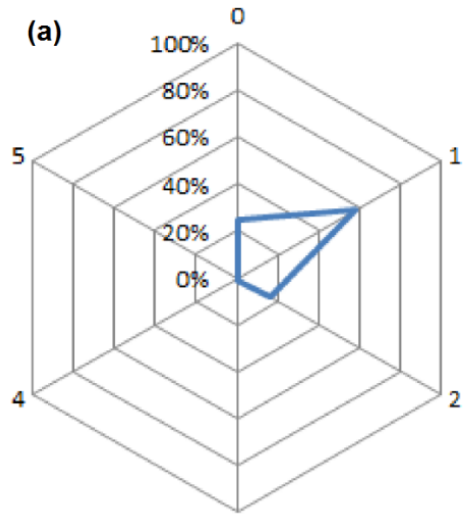

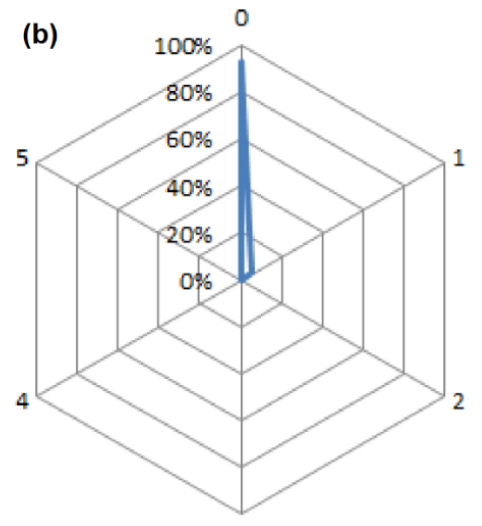

Figure 7. Percent contribution of frequency of occurrence of particular odor intensity values in receptor points outside the premises of the WWTP: (a) before modernization; (b) after modernization. 
This quite evident positive result of the assessment of the change in the odor impact of the WWTP does not exclude the occurrence of odor episodes outside its area, and simultaneously requires continued work to comply with the technological regime and good practices in the process of wastewater treatment, as well as processing of sludge and waste neutralization.

\section{Discussion}

Next to the basic, typical sources of odors at the WWTP, locations with high odor potential within the WWTP include, inter alia, screening facilities and flow equalization basins, and secondary clarifiers constitute low/moderate potential odor sources. Moreover, the locations of anaerobic digestion, sludge storage basins, and mechanical dewatering exhibit moderate/high odor potential [53]. In the present study, the secondary settling tank has low, while the screening processing line has high odor potential (especially its last stage, where screens were stored in an open space area). Therefore, field tests of WWTPs should be preceded by an extensive local vision, not only on the premise of focusing on primary sources. D/T values near the fence lines of the WTTP were between 0 and 300, while the highest values were detected in the storage yard of dewatered sludge near the border of the plant. These results confirm the conclusions that odor emission and nuisance problem is more serious in areas with objects with a much larger and usable surface area, such as a sludge processing and management line [24]. According to other researchers [24,54,55], particularly in the headwork and truck loading part [56], odor intensity in the "sludge area" is between 3 (distinct) and 5 (strong)—similar values were observed in this article. Sulphur, ammonia, and fecal odors indicate microbiological degradation; in the case of dewatered and stored biosolids with high solid content, emissions are affected by upstream digestion, dewatering, and storage [57]. Odor concentration values from points located on piles of dewatered sludge were between 557 and $5091 \mathrm{ou} / \mathrm{m}^{3}$ [21]. These values depend on the storage time- the early active phase and turning showed the highest odor emission rates [58], whereas in this study, values from 2 to $549 \mathrm{ou} / \mathrm{m}^{3}$ were found in the immediate vicinity of the piles. These results overlap with values obtained by Gonzalez et al., because those researchers obtained the lowest values for sludge aged greater than 10 days [21] — the storage age of piles tested in the scope of this article was above one month. Wang et al. measured odor concentrations in the sludge dewatering building, and obtained D/T values from 6 to $790 \mathrm{ou} / \mathrm{m}^{3}$ [59], while in the present research, D/T values in the in the closest distance from the sludge dewatering building ranged from 4 to $448 \mathrm{ou} / \mathrm{m}^{3}$. D/T values detected near the fence lines close to the mechanical-biological treatment area were between 0 and 30 . The results are similar to those obtained by Witherspoon and Barnes-Nasal Ranger ${ }^{\circledR}$. D/T values near the fence lines of the WTTP were, according to their research, between 0 and 30 [60], while Cesca et al. obtained values from 2 to 7 [61]. Capelli et al. obtained the following results of geometric mean of odor concentration values: Pre-treatments: $2260 \mathrm{ou} / \mathrm{m}^{3}$; biological reactors area: $180 \mathrm{ou} / \mathrm{m}^{3}$; secondary sedimentation: $124 \mathrm{ou} / \mathrm{m}^{3}$; sludge thickening: $2150 \mathrm{ou} / \mathrm{m}^{3}$; sludge storage: $676 \mathrm{ou} / \mathrm{m}^{3}$ [62]. Odor concentration values of the WWTP biofilters were between 67 and $95 \mathrm{ou} / \mathrm{m}^{3}$ [63], while in the present study, these values were between 3 and $22 \mathrm{ou} / \mathrm{m}^{3}$. Byliński et al. studied the concentration of odor in the surroundings of the following sources: Hall of mechanical treatment (HMT), biological reactors area (BRA), and sludge composting piles (SCP). In summer and spring, the researchers obtained the following maximum odor concentration values: HMT: $22 \mathrm{ou} / \mathrm{m}^{3}$ (this study: $\left.68 \mathrm{ou} / \mathrm{m}^{3}\right)$; BRA: $12 \mathrm{ou} / \mathrm{m}^{3}\left(22 \mathrm{ou} / \mathrm{m}^{3}\right)$; SCP: $24 \mathrm{ou} / \mathrm{m}^{3}$ $\left(549 \mathrm{ou} / \mathrm{m}^{3}\right)$ [20]. The estimated odor concentration decreased sharply with distance downwind to the WW, reaching a value of $2 \mathrm{ou} / \mathrm{m}^{3}$ at a distance $200 \mathrm{~m}$ from the source [64]. The current research has confirmed these results-for the majority of sources, the impact range was less than $200 \mathrm{~m}$, but piles of dewatering sludge had an odor effect of up to $600 \mathrm{~m}$ from the source.

\section{Summary and Conclusions}

The field research concerning the odor impact of technological objects of the WWTP before and after the completion of the process of its modernization and enlargement included 22 series covering a total of 804 olfactometric measurements and meteorological measurements and observations. Results of 
the performed measurements and observations were used for the detailed analysis of the impact of the objects of the WWTP, and formulation of conclusions in the scope of their nuisance for the surroundings. As a result, the degree of odor nuisance (type and range) of the WWTP was determined. The study results provided the basis for the following conclusions:

- Air inflowing over the area of the WWTP was clean in terms of odor. The level of the so-called background for odor intensity and concentration was zero. This means no occurrence (no identification) of sources of emission of odorants/odors, the impact of which would overlap with the impact of the analyzed object.

- In the area of the wastewater treatment installation-before and after modernization-odor intensity changed in a complete range (from $i=0$ to $i=5$ ), and odor concentration from 0 to $549 \mathrm{ou} / \mathrm{m}^{3}$.

- Sources emitting odor with a maximum concentration value of $549 \mathrm{ou} / \mathrm{m}^{3}$ were piles of dewatered sludge in the waste storage yard.

- Other odorant emitters included, in order of the degree of odor nuisance: A small heap of screenings deposited in the waste storage yard after modernization (maximum odor concentration value $319 \mathrm{ou} / \mathrm{m}^{3}$ ), and a container for dewatered sludge located at a distance of $10 \mathrm{~m}$ south of the building of mechanical sludge thickening and dewatering. During its filling with sludge from the sludge dewatering building, the maximum odor concentration value before modernization was $450 \mathrm{ou} / \mathrm{m}^{3}$, while after modernization, $123 \mathrm{ou} / \mathrm{m}^{3}$.

- The source of odor of raw sewage and screenings was the screens building. The maximum odor concentration value was $68 \mathrm{ou} / \mathrm{m}^{3}$ (that value was achieved after modernization). Insufficient air-tightening of the object (crevice under the gate of the screens hall) contributed to spreading of odorous substances.

- Odor impact outside the WWTP was determined in three out of the twelve performed series of olfactometric research concerning air quality. In these cases, odor of screenings from the screens building and a small heap of screenings was observed, as well as odor of dewatered sludge from the piles deposited in the sludge storage yard. The maximum range of impact of the WWTP was $580 \mathrm{~m}$, and the maximum odor concentration value recorded outside the plant reached $3 \mathrm{ou} / \mathrm{m}^{3}$.

- Modernization and enlargement of the technological sequence of biological reactors and secondary settling tanks had no effect on the emission of odorants from the objects.

- During all the series of field research, the plant's gas station in the north-eastern part of the WWTP was determined not to constitute a source of odor impact.

Author Contributions: Conceptualization, A.K. and M.S.-S.; methodology, A.K. and M.S.-S.; software, M.S.-S.; validation, A.K. and M.S.-S.; formal analysis, A.K. and M.S.-S.; investigation A.K. and M.S.-S.; resources, A.K. and M.S.-S.; data curation, A.K. and M.S.-S.; writing-original draft preparation, A.K. and M.S.-S.; writing-review and editing, A.K. and M.S.-S.; visualization, M.S.-S.; supervision, A.K.; project administration, A.K.; funding acquisition, A.K.

Funding: Article publishing was funded by Dean of Faculty of Building Services, Hydro and Environmental Engineering, Warsaw University of Technology.

Conflicts of Interest: The authors declare no conflict of interest.

\section{References}

1. Badach, J.; Kolasińska, P.; Paciorek, M.; Wojnowski, W.; Dymerski, T.; Gębicki, J.; Dymnicka, M.; Namieśnik, J. A case study of odour nuisance evaluation in the context of integrated urban planning. J. Environ. Manag. 2018, 213, 417-424. [CrossRef] [PubMed]

2. Runhaar, H.; Driessen, P.P.J.; Soer, L. Sustainable urban development and the challenge of policy integration: An assessment of planning tools for integrating spatial and environmental planning in The Netherlands. Environ. Plan. 2019, 36, 417-431. [CrossRef] 
3. Wu, C.; Brancher, M.; Yang, F.; Liu, J.; Qu, C.; Schauberger, G.; Piringer, M. A Comparative Analysis of Methods for Determining Odour-Related Separation Distances around a Dairy Farm in Beijing, China. Atmosphere 2019, 10, 231. [CrossRef]

4. Adams, G.; Witherspoon, J. Identifying and controlling odor in the municipal wastewater environment phase 1: Literature search and review. IWA Publ. 2003, 3. [CrossRef]

5. Brancher, M.; Griffiths, K.D.; Franco, D.; de Melo Lisboa, H. A review of odour impact criteria in selected countries around the world. Chemosphere 2017, 168, 1531-1570. [CrossRef] [PubMed]

6. Brambilla, M.; Navarotto, P. Sensorial analysis of pig barns odour emissions. Chem. Eng. Trans. 2010, 23, 243-248. [CrossRef]

7. Guffanti, P.; Pifferi, V.; Falciola, L.; Ferrante, V. Analyses of odours from concentrated animal feeding operations: A review. Atmos. Environ. 2018, 175, 100-108. [CrossRef]

8. Hansen, M.J.; Jonassen, K.E.N.; Lokke, M.M.; Adamsen, A.P.S.; Feilberg, A. Multivariate prediction of odor from pig production based on in-situ measurement of odorants. Atmos. Environ. 2016, 135, 50-58. [CrossRef]

9. Harrison, E.Z.; Oakes, S.R. Investigation of alleged health incidents associated with land application of sewage sludges. New Solut. 2002, 12, 387-408. [CrossRef] [PubMed]

10. Hayes, J.E.; Stevenson, R.J.; Stuetz, R.M. The impact of malodour on communities: A review of assessment techniques. Sci. Total Environ. 2014, 500-501, 395-407. [CrossRef] [PubMed]

11. Gostelow, P.; Parsons, S.A.; Stuetz, R. Odour measurements for the sewage treatment works. Water Res. 2001, 35, 579-597. [CrossRef]

12. Pan, L.; Yang, S.X.; de Bruyn, J. Factor analysis of downwind odours from livestock farms. Biosyst. Eng. 2007, 96, 387-397. [CrossRef]

13. Rappert, S.; Muller, R. Odor compounds in waste gas emissions from agricultural operations and food industries. Waste Manag. 2005, 25, 887-907. [CrossRef] [PubMed]

14. Shusterman, D. The health significance of environmental odour pollution: Revisited. J. Environ. Med. 1999, 1, 249-258. [CrossRef]

15. Toledo, M.; Diles, J.A.; Gutierrez, M.C.; Martin, M.A. Monitoring of the composting process of different agroindustrial waste: Influence of the operational variables on the odorous impact. Waste Manag. 2018, 76, 266-274. [CrossRef] [PubMed]

16. Van Harreveld, A.P. Odour management tools-Filling in the gaps. Water Sci. Technol. 2004, 50, 1-8. [CrossRef] [PubMed]

17. Wi, J.; Lee, S.; Kim, E.; Lee, M.; Koziel, J.; Ahn, H. Evaluation of Semi-Continuous Pit Manure Recharge System Performance on Mitigation of Ammonia and Hydrogen Sulfide Emissions from a Swine Finishing Barn. Atmosphere 2019, 10, 170. [CrossRef]

18. Zhu, W.; Koziel, J.; Maurer, D.L. Mitigation of Livestock Odors Using Black Light and a New Titanium Dioxide-Based Catalyst: Proof-of-Concept. Atmosphere 2017, 8, 103. [CrossRef]

19. Agus, E.; Zhang, L.; Sedlak, D.L. A framework for identifying characteristic odor compounds in municipal wastewater effluent. Water Res. 2002, 46, 5970-5980. [CrossRef] [PubMed]

20. Byliński, H.; Gębicki, J.; Namieśnik, J. Evaluation of Health Hazard Due to Emission of Volatile Organic Compounds from Various Processing Units of wastewater treatment plant. Int. J. Environ. Res. Public Health 2019, 16, 1712. [CrossRef] [PubMed]

21. Gonzalez, D.; Colon, J.; Sanchez, A.; Gabriel, D. A systematic study on the VOCs characterization full-scale sewage sludge composting plant. J. Hazard. Mater. 2019, 373, 733-740. [CrossRef] [PubMed]

22. Cieślik, B.M.; Namieśnik, J.; Konieczka, P. Review of sewage sludge management: Standards, regulations and analytical methods. J. Clean. Prod. 2015, 90, 1-15. [CrossRef]

23. Bruszkiewski, H.; Skorupski, W. Air pollution caused by a concentrated liquid waste treatment plant. Chem. Inżynieria Ekol. 1999, 10, 979-987.

24. Lewkowska, P.; Cieślik, B.; Dymerski, T.; Konieczka, P.; Namieśnik, J. Characteristics of odors emitted from municipal wastewater treatment plant and methods for their identification and deodorization techniques. Environ. Res. 2016, 151, 573-586. [CrossRef] [PubMed]

25. Aatamila, M.; Verkasalo, P.K.; Korhonen, M.J.; Suominen, A.L.; Hirvonen, M.-R.; Viluksela, M.K.; Nevalainen, A. Odour annoyance and physical symptoms among residents living near waste treatment centres. Environ. Res. 2011, 111, 164-170. [CrossRef] [PubMed] 
26. Fang, J.J.; Yang, N.; Cen, D.Y.; Shao, L.M.; He, P.J. Odor compounds from different sources of landfill: Characterization and source identification. Waste Manag. 2012, 32, 1401-1410. [CrossRef] [PubMed]

27. González, I.; Robledo-Mahón, T.; Silva-Castro, G.A.; Rodríguez-Calvo, A.; Gutiérrez, M.C.; Martín, M.A.; Chica, A.F.; Calvo, C. Evolution of the composting process with semi-permeable film technology at industrial scale. J. Clean. Prod. 2016, 115, 245-254. [CrossRef]

28. Gutiérrez, M.C.; Martin, M.A.; Chica, A.F. Usual variables and odour concentration to evaluate composting process and odour impact. Environ. Technol. 2014, 35, 709-718. [CrossRef] [PubMed]

29. Kulig, A.; Szyłak-Szydłowski, M. Assessment of Range of Olfactory Impact of Plant to Mechanical-Biological Treatment of Municipal Waste. Chem. Eng. Trans. 2016, 54, 247-252. [CrossRef]

30. Sironi, S.; Capelli, L.; Céntola, P.; Del Rosso, R.; Pierucci, S. Odor impact assessment by means of dynamic olfactometry, dispersion modelling and social participation. Atmos. Environ. 2010, 44, 354-360. [CrossRef]

31. Szyłak-Szydłowski, M. Odour Samples Degradation During Detention in Tedlar ${ }^{\circledR}$ Bags. Water Air Soil Pollut. 2015, 226, 38-52. [CrossRef] [PubMed]

32. Szyłak-Szydłowski, M. Validation of odor concentration from mechanical-biological treatment piles using static chamber and wind tunnel with different wind speed values. J. Air Waste Manag. Assoc. 2017, 67, 1046-1054. [CrossRef] [PubMed]

33. Barczak, R.; Kulig, A.; Szyłak-Szydłowski, M. Olfactometric methods application for odour nuisance assessment of wastewater treatment facilities in Poland. Chem. Eng. Trans. 2012, 30, 187-192. [CrossRef]

34. Blanes-Vidal, V.; Hansen, M.N.; Adamsen, A.P.S.; Feilberg, A.; Petersen, S.O.; Jensen, B.B. Characterization of odor released during handling of swine slurry: Part, I. Relationship between odorants and perceived odor concentrations. Atmos. Environ. 2009, 43, 2997-3005. [CrossRef]

35. Hobbs, P. Odour analysis by gas chromatography. In Odours in Wastewater Treatment: Measurement, Modelling and Control; Stuetz, R.M., Frechen, F.-B., Eds.; IWA Publishing: London, UK, 2001.

36. Tsai, C.J.; Chen, M.L.; Ye, A.D.; Chou, M.S.; Shen, S.H.; Mao, I.F. The relationship of odor concentration and the critical components emitted from food waste composting plants. Atmos. Environ. 2008, 42, 8246-8251. [CrossRef]

37. Dincer, F.; Muezzinoglu, A. Odor determination at wastewater collection systems: Olfactometry versus $\mathrm{H}_{2} \mathrm{~S}$ analyses. Clean 2007, 35, 565-570. [CrossRef]

38. Gostelow, P.; Parsons, S.A. Sewage treatment works odor measurement. Water Sci. Technol. 2000, 41, 33-40. [CrossRef]

39. Wang, B.; Sivret, E.C.; Parcsi, G.; Wang, X.; Stuetz, R.M. Characterising volatile organic compounds from sewer emissions by thermal desorption coupled with gaschromatography-mass spectrometry. Chem. Eng. Trans. 2012, 30, 73-78. [CrossRef]

40. Nicell, J.A. Assessment and regulation of odour impacts. Atmos. Environ. 2009, 43, 196-206. [CrossRef]

41. Brattoli, M.; de Gennaro, G.; de Pinto, V.; Loiotile, A.D.; Lovascio, S.; Penza, M. Odour Detection Methods: Olfactometry and Chemical Sensors. Sensors 2011, 11, 5290-5322. [CrossRef] [PubMed]

42. Capelli, L.; Sironi, S.; Del Rosso, R. Electronic noses for environmental monitoring applications. Sensors 2014, 14, 19979-20007. [CrossRef] [PubMed]

43. McGinley, C. Standardized odor measurement practices for air quality testing. In Proceedings of the Air and Waste Management Association Symposium on Air Quality Measurement, Methods and Technology, San Francisco, CA, USA, 13-15 November 2002.

44. Frechen, F.B. Regulations and policies. In Odours in Wastewater Treatment: Measurement, Modelling and Control; Stuetz, R.M., Frechen, F.-B., Eds.; IWA Publishing: London, UK, 2001.

45. Cheng, X.H.; Peterkin, E.; Narangajavana, K. Wastewater analysis for volatile organic sulfides using purge-and-trap with gas chromatography/mass spectrometry. Water Environ. Res. 2007, 79, 442-446. [CrossRef] [PubMed]

46. Munoz, R.; Sivert, E.C.; Parcsi, G.; Lebrero, R.; Wang, X.; Suffet, I.H.; Stuetz, R.M. Monitoring techniques for odour abatement assessment. Water Res. 2010, 44, 5129-5149. [CrossRef] [PubMed]

47. Szyłak-Szydłowski, M. Comparison of two types of field olfactometers for assessing odours in laboratory and field tests. Chem. Eng. Trans. 2014, 40, 67-72. [CrossRef]

48. Turkmen, M.; Dentel, S.K.; Chiu, P.C.; Hepner, S. Analysis of sulfur and nitrogen odorants using solid-phase microextraction and GC-MS. Water Sci. Technol. 2004, 50, 115-120. [CrossRef] [PubMed] 
49. VDI 3940 Part 2: Measurement of Odour Impact by Field Inspection-Measurement of the Impact Frequency of Recognizable Odours Plume Measurement. Available online: https: //www.nhbs.com/vdi-3940-part-2-measurement-of-odour-impact-by-field-inspection-measurement-ofthe-impact-frequency-of-recognizable-odours-plume-measurement-book (accessed on 12 November 2019).

50. Belgiorno, V.; Naddeo, V.; Zarra, T. Odour Impact Assessment Handbook, 1st ed.; John Wiley \& Sons Ltd.: London, UK, 2013.

51. Dentoni, L.; Capelli, L.; Sironi, S.; Guillot, J.-M.; Rossi, A.N. Comparison of different approaches for odour impact assessment: Dispersion modelling (CALPUFF) vs field inspection (CEN/TC 264). Water Sci. Technol. 2013, 68, 1731-1737. [CrossRef] [PubMed]

52. Eusebio, L.; Dentoni, L.; Capelli, L.; Sironi, S.; Rossi, A.N.; Bonati, S. Odour impact assessment in the field: The plume method. Environ. Eng. Manag. J. 2013, 12, 193-196.

53. Karageorgos, P.; Latos, M.; Kotsifaki, C.; Lazaridis, M.; Kalogerakis, N. Treatment of unpleasant odors in municipal wastewater treatment plants. Water Sci. Technol. 2010, 61, 2635-2644. [CrossRef] [PubMed]

54. Doshi, V.A.; Vuthaluru, H.; Bastow, T. Investigations into the control of odour and viscosity of biomass oil derived from pyrolysis of sewage sludge. Fuel Process. Technol. 2005, 86, 885-897. [CrossRef]

55. Fisher, R.M.; Le-Minh, N.; Sivret, E.C.; Alvarez-Gaitan, J.P.; Moore, S.J.; Stuetz, R.M. Distribution and sensorial relevance of volatile organic compounds emitted throughout wastewater biosolids processing. Sci. Total Environ. 2017, 599-600, 663-670. [CrossRef] [PubMed]

56. Zhou, Y.; Hallis, S.A.; Vitko, T.; Suffet, I.H. Identification, quantification and treatment of fecal odors released into the air at two wastewater treatment plants. J. Environ. Manag. 2016, 180, 257-263. [CrossRef] [PubMed]

57. Fisher, R.; Barczak, R.; Suffet, I.H.; Hayes, E.J.; Stuetz, R.M. Framework for the use of odour wheels to manage odours throughout wastewater biosolids processing. Sci. Total Environ. 2018, 634, 214-223. [CrossRef] [PubMed]

58. Rincon, C.A.; De Guardia, A.; Couvert, A.; Soutrel, I.; Guezel, S.; Le Serrec, C. Odor generation patterns during different operational composting stages of anaerobically digested sewage sludge. Waste Manag. 2019, 95, 661-673. [CrossRef] [PubMed]

59. Wang, T.; Sattayatewa, C.; Venkatesan, D.; Noll, K.E.; Pagilla, K.R.; Moschandreas, D.J. Modeling indoor odoreodorant concentrations and the relative humidity effect on odor perception at a water reclamation plant. Atmos. Environ. 2011, 45, 7235-7239. [CrossRef]

60. Witherspoon, J.R.; Barnes, J.L. Comparison of methods used to measure odour at wastewater treatment plant fencelines. In Proceedings of the Environmental Odour Management International Conference, Cologne, Germany, 17-19 November 2004; pp. 363-375.

61. Cesca, J.; Flanagan, A.; Cunnington, M. Case Study: Odour Risk Management at the WTP, One of Australia's Largest Most Unique WWTPs. Semanticscholar 2007. Available online: https://www.semanticscholar.org/paper/Case-Study-\%3A-Odour-Risk-Management-at-the-WTP\%2C-One-Cesca/fe6236cff0b15c65d5ce3aaa793c6b4ada6783a2 (accessed on 12 November 2019). [CrossRef]

62. Capelli, L.; Sironi, S.; Del Rosso, R.; Centola, P. Predicting odour emissions from wastewater treatment plants by means of odour emission factors. Water Res. 2009, 43, 1977-1985. [CrossRef] [PubMed]

63. Littarru, P. Environmental odours assessment from waste treatment plants: Dynamic olfactometry in combination with sensorial analysers electronic noses. Waste Manag. 2007, 22, 302-309. [CrossRef] [PubMed]

64. Stellacci, P.; Liberti, L.; Notarnicola, M.; Haas, C.N. Hygienic sustainability of site location of wastewater treatment plants: A case study. I. Estimating odour emission impact. Desalination 2010, 253, 51-56. [CrossRef]

(C) 2019 by the authors. Licensee MDPI, Basel, Switzerland. This article is an open access article distributed under the terms and conditions of the Creative Commons Attribution (CC BY) license (http://creativecommons.org/licenses/by/4.0/). 